\title{
UK ENERGY
}

BRITAIN's "Save It" energy conservation campaign clearly doesn't apply to the increasingly protracted debates on the subject itself. Not that the energy spent discussing the issues is entirely wasted, even though it certainly looked that way three weeks ago when the latest rush of events was about to start.

What research and development was in hand, a backbench MP asked, and what new technology developed, so that alternative sources of energy could, if economic, be rapidly exploited? Mr Anthony Wedgwood Benn, Secretary of State for Energy and Britain's principal advocate of open government, was simply uninformative:

Considerable research and development is in hand on indigenous raw materials which are or might be sources of energy. Much of this work is carried out by the nationalised energy industries, the United Kingdom Atomic Energy Authority (UKAEA), the nuclear industry and the oil companies. In the field of new nonnuclear energy sources, my Energy Technology Support Unit has carried out assessment studies. Research and development programmes are being drawn up for those areas which show most promise of making a significant contribution to the country's energy needs. The United Kingdom agencies also participate in international energy research programmes, such as those of the European Communities and the International Energy Agency.

Just three days later $\mathrm{Mr}$ Benn's department launched a major research programme on wave power.

It was an unjustifiably inauspicious start to a period of great activity on the alternative energy front. Whether the MP was anticipating the announcement is not known. If he hoped to probe behind the veil shielding the department's Energy Technology Support Unit (ETSU), he did not have too long to wait before another attempt was made. Three top men from ETSU gave evidence the following week to the Energy Resources Sub-committee of the House of Commons Select Committee on Science and Technology. They offered little hint of the content of the Department of Energy's proposed research and development programme for existing and new sources of encrgy-that had to wait another week, until the Department of Energy's Chief Scientist, Dr Walter Marshall, appeared before the committec on behalf of the Advisory Council on Research and Development for Fuel and Power (ACORD). ACORD has now passed on that programme to $\mathrm{Mr}$ Benn.

But ETSU was not totally unforthcoming. It confirmed that it was placing contracts on behalf of the department and was thus playing a supervisory, monitoring role as well as performing its specified tasks on energy sources and energy conservation. ETSU also revealed its preferential ordering of alternative energy sources: wave power offered the "best potential contribution" and looked the most promising; solar came next, ahead of geothermal; wind and tidal power together took up the rear.

Without some sort of weighting, it all seemed rather crude. The subsequent ACORD hearing indicated that ETSU's chief concerns have been solar, geothermal and wind power; wave power studies were the province of the National Engineering Laboratory, while the Central Electricity Generating Board investigated tidal power. Obviously there is close collaboration, not least through the ubiquitous $\mathrm{Dr}$ Marshall and a plethora of committees. ACORD, in particular, is crucial. With members drawn from the nationalised fuel and power industries (coal, gas and electricity), from the oil industry, from research bodies (the SRC and the UKAEA) and from the academic world, it considers the results of ETSU's technical studies and advises $\mathrm{Mr}$ Benn on both research and development needs and the size of appropriate programmes drawn up by steering committees.

Thus it was able to confirm ETSU's preference to the select committee: it had considered tidal power (AprilMay 1975), and ordered a limited study of technical issues relating to the Severn Barrage; wave power (June 1975), which produced the $£ 1$ million feasibility study launched at the end of last month; geothermal energy (October 1975), any research programme on which needs to be integrable with the EEC's work in the area; wind cnergy (December 1975), about which a decision was deferred pending further study of costs; and solar energy (February 1976).

It was, in fact, solar energy's turn to capture some attention by this time, thanks to the publication of a massive document by the UK section of ISES, the International Solar Encrgy Society (see page 177). The bullish tone it adopts about solar energy prospects contrasts with the apparent view of ACORD. ACORD "accepts in nrinciple the nced for a national $R$ \& D programme" and wants a more detailed study, backed by research and development, "to define the options more precisely"--in other words, the case for solar energy, at least as presented to it by ETSU, is not yet absolutely proven.

Whether all this reflects a genuine clash of views over priorities will probably only emerge after the oneday "national energy conference" organised by $\mathrm{Mr}$ Benn for June 22; ACORD's recommendations to $\mathrm{Mr}$ Benn are to be made public the same day. The 50 organisations invited to this more obvious example of open government include representatives of industry, the unions, consumer, conservation and environmental interests, and professional, academic and research bodies. In the meantime, the ISES document is an attempt to reinforce the case for solar energy. Clearly the circle of interests that the subject of energy now covers is widening fast.

So fast, in fact, that the issues involved in alternative energy seem to be growing increasingly political - partly thanks to Mr Benn, but principally because the potential of the various energy sources under scrutiny turns less on the well documented scientific evidence that can be brought to bear than on the impenetrable economic factors involved. The ISES document provides just one example: the case it puts for solar energy is based on more than mere scientific feasibility, but it is not really couched in the propagandist terms typical of a document urging policy changes. As one environmentalist privately pointed out, though, it does provide excellent ammunition.

Alternative energy, however, is but the tip of the iceberg, as any table of comparative expenditures on energy in Britain would quickly show. And as if to add to the recent excitement, the Energy Research Group at the Open University has churned out its own critique of the electricity industry, advocating a national fuel policy and suggesting that sheer overestimation of demand has produced a large measure of overcapacity. It can't be long before the fact that power is consumed to such a large extent in the form of electricity also becomes a legitimate area of enquiry.

Back in the committee rooms of the House of Commons, however, was the poor Science Research Council (SRC), also giving a view on alternative energy resources-the beleaguered Sir Sam Edwards was in the chair. He took the opportunity to cock a snook at the Treasury: in an obvious reference to the condition of "big" science under the SRC, he indicated that even if it was available extra money would not be devoted to alternative energy. 